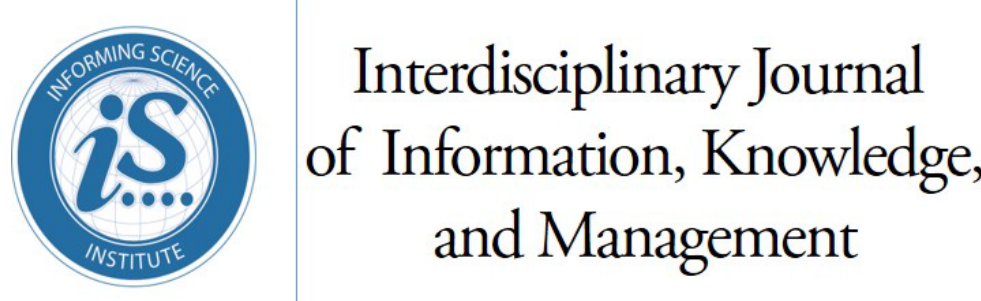

An Official Publication

of the Informing Science Institute

InformingScience.org

IJIKM.org

Volume 12, 2017

\title{
TRANSFORMING COMMUNICATIONS IN THE WORKPLACE: THE IMPACT OF UC ON PERCEIVED ProduCTIVITY IN A MULTI-NATIONAL CORPORATION
}

Joy Fluker

Meg Murray*

* Corresponding author
Kennesaw State University, Kennesaw, GA USA

Kennesaw State University, Kennesaw, GA USA
Loy.fluker@yahoo.com

mcmurray@kennesaw.edu

\section{ABSTRACT}

Aim/Purpose

Unified Communications (UC) is touted as a technology that will transform business communication. While positive claims abound, the factors of UC attributable to its success have yet to be identified. By examining how users perceive UC impacts productivity, this study aids organizations in making better decisions regarding investments in and usage of communications technologies.

Background Unified Communications integrates disparate communications and information sharing applications into a single platform. The promise of UC is that it will revolutionize the workplace by providing a more synchronized fit between the way people communicate and the technology they use.

Methodology

$$
\text { Through case study research conducted within a large multinational corporation }
$$
(the Hewlett Packard Company), this study investigated the impact of UC on productivity. Interview narratives were examined using an open coding technique to capture individual perceptions of productivity. Further, to assess the role UC plays in facilitating relationship building and its connection to productivity, participant responses were mapped to the key factors of technology that influence relationships within an organization as identified by Dillon and Montano (2005).

Contribution This research contributes to studies on the impact of UC on productivity in the workplace.

Findings UC was found to increase personal productivity, remove communication barriers, and create a more positive work environment.

Recommendations The findings of this study will aid organizations in making investment decisions for Practitioners as they evolve their business communications strategy.

Accepted by Editor Elsje Scott | Received: January 14, 2017| Revised: March 14, April 14, 29, 2017 | Accepted: May 5, 2017.

Cite as: Fluker, J., \& Murray, M. (2017). Transforming communications in the workplace: The impact of UC on perceived productivity in a multi-national corporation. Interdisciplinary Journal of Information, Knowledge, and Management, 12, 175-187. Retrieve from http://www.informingscience.org/Publications/3740

(CC BY-NC 4.0) This article is licensed to you under a Creative Commons Attribution-NonCommercial 4.0 International License. When you copy and redistribute this paper in full or in part, you need to provide proper attribution to it to ensure that others can later locate this work (and to ensure that others do not accuse you of plagiarism). You may (and we encourage you to) adapt, remix, transform, and build upon the material for any non-commercial purposes. This license does not permit you to use this material for commercial purposes. 
Transforming Communications in the Workplace

Impact on Society Unified Communications will play an increasingly important role as people adapt to the evolving digital world through which they communicate and collaborate.

Future Research Little research exists that examines the impact of UC within an organization. Additional research investigating the use of UC in a variety of business sectors is needed.

Keywords Unified Communications (UC), business communications, communications channels, perceived productivity

\section{INTRODUCTION}

Communication has long been recognized as a critical success factor in business and advances in technology have enabled multiple communications channels. A note in terminology needs to be made here. Communication refers to the exchange of information between people. Communications is a technical term that refers to the means used to transmit the messages. Therefore, terms such as communications channel, or its synonym, communications medium, are used when referring to the technology employed to facilitate the act of communicating. The rapid increase in the number and type of communications technologies available in the workplace has made it difficult for the business user to navigate the evolving communications landscape. Businesses across the globe recognize a need to bring together all communications and collaboration channels, including telephony, video, chat (instant messaging), email, file and applications sharing, to facilitate streamlined interactions between colleagues, customers, suppliers, and partners (Cross, 2013). Unified Communications (UC) represents innovation in the communications technology space. UC is positioned as an enterprise level solution that integrates heterogeneous communications channels and collaboration technologies to facilitate the interactive use of multiple communication methods and information sharing activities (Elliot, Blood, \& Fernandez, 2016). A major strength of these technologies is the incorporation of features that include contextual presence tracking providing information about individual availability and communication method preference, on-demand switching between communications channels, and intelligent notification services (Gartner, 2013). However, UC is not about a checklist of features; it is about creating a holistic and dynamic approach to an organizational communication strategy that spans people, processes, and technology (Bolton, Murray \& Fluker, 2017). The primary goal of unified communications is to improve user productivity and enhance the way business is done (Elliot et al., 2016).

The technical benefits of a UC infrastructure have been widely touted but the workplace benefits may be more compelling (Cross, 2013). Studies have found that UC has a positive impact on company financials. UC has been shown to increase revenue opportunities, reduce costs, and improve customer satisfaction (Jamison \& Pleasant, 2008). UC also, notably, changes the ways users do their jobs resulting in improvements in personal and workgroup performance and productivity (Pleasant \& Jamison, 2008). According to Weihua (2011), users of UC benefit from reduced delays in decisionmaking resulting in speedier workflows, convenience of knowledge and information transfer, support to strengthen relationships with peers across countries and time zones, and the provision of real-time accessibility to other people. Strong relationships encourage collaboration and collaboration is a key driver for business performance, innovation, and productivity (Kristensen \& Kinjal, 2010). We posit, as shown in Figure 1, that the features of UC enable better communication, thereby facilitating relationship building ultimately contributing to a positive impact on productivity.

In this research, we studied the use of UC in global virtual teams in a multinational corporation, namely Hewlett Packard Company, a company reported to be one of the largest organizations to execute a comprehensive unified communications rollout. Through case study analysis, we examine how users perceive UC impacts productivity. We also assess user preference for various UC communications mediums. Due to the growing market trend for UC and reports espousing its benefits, developing a deeper understanding and refined analysis of the significance of those benefits is needed. 
This research has practical implication as it aids organizations in making better decisions in regard to their investments in and usage of communications technologies in a global environment.

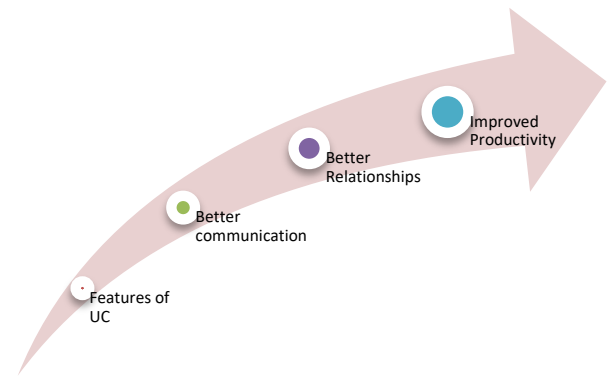

Figure 1. Path to Productivity

\section{REVIEW OF THE LITERATURE}

Unified Communications has evolved over time. Its roots are found with communications technologies such as Instant Messaging (IM or chat) and later Unified Messaging (UM), a set of communications options that includes text messaging, email, and IM. Today, most UC solutions provide singleplatform support for telephony, audio, chat (text messaging), video, file and application sharing, presence management, and mobile interaction. UC adoption is growing rapidly. The UC market is projected to reach $\$ 75.81$ billion [increase of $16.3 \%$ ] by 2020 (Grand Review Research, 2015). The expectation is that $\mathrm{UC}$ will transform the workplace by providing a more synchronized fit between the way people communicate and the technology they use. The promise of UC is that it will improve collaboration between employees, business partners, and customers and, thereby, increase employee productivity (Riemer \& Taing, 2009).

Productivity is an essential element of competitiveness and sustainable growth, and productivity measurement is a critical tool in the management process (Kongkiti, Anussornnitisarn, Sujitwanit, \& Kess, 2009). Productivity is generally described as the ratio between output relative to input. The Encyclopedia of Management qualifies this by stating: "More specifically, productivity is the measure of how specified resources are managed to accomplish timely objectives as stated in terms of quantity and quality" (Inman, 2015). Measuring productivity, however, can be challenging. For example, businesses or even business units within an organization offer varying types of services for which factors of productivity may be defined differently (Jääskeläinen \& Uusi-Rauva, 2011). Measuring the impact of IT investments on productivity is further complicated as beneficial effects often occur over the long-term (Kunsoo, Young, \& Jungpil, 2010). Consequently, while positive claims abound, there is still very little research available that identifies specific factors attributed to productivity gains realized through the implementation of a UC solution.

Strong working relationships among team members, regardless of physical proximity, is the foundation of how most work is completed and goals are accomplished (Ferris, Linden, Munyon, Summers, Basik, \& Buckley, 2009). UC provides a multi-faceted communications infrastructure that facilitates the communication that drives relationship building. Dillon and Montano (2005) investigated how information technology impacts relationships within various levels of an organization. Specifically, they found technology that expedites ease of communication among individuals strengthens their feelings toward the groups to which they belong, and even stronger connections are realized as more people use the same technology. Further, always available communications channels and information linkages promote strong, positive relationships between group members (Dillon \& Montano, 2005). On the other hand, user affinity and purposeful intention to use a technology, play a role in how effective the technology will be in facilitating relationship building (Lowry, Cao, \& Everard, 2011).

Dillon and Montano (2005) identified eight technology variables that impact relationship building within an organization. They categorized these variables into two different classifications, perfor- 
mance factors emphasizing the technologies employed for communications and human factors emphasizing the people involved in the communication (p. 232). Performance factors include convenience or ease-of-use, relevance or appropriateness of the technology for the task at hand, and informativeness or the ability to provide desired information when needed. Human factors are further divided into two subgroups, 'unifying' referring to factors that create group identification or 'distinguishing' referring to factors that recognize individuality. Within a technology context, unifying factors include the ability of the technology to facilitate feelings of connectedness, membership, and entitlement. Distinguishing factors include the ability of the technology to support both customization and differentiation. The Dillon and Montano framework provides a useful way to assess the impact of UC on relationship building. Features common to a UC platform are easily mapped to the framework. For example, performance factors are exemplified as UC provides the ability to easily choose an appropriate communications medium from a multitude of options and then switch between mediums by a simple click of a mouse. Group identification and feelings of connection, membership, and entitlement are facilitated through sharable user profiles, the ability to create and customize group membership, and the ability to tailor features and privileges by group designation. Differentiation and customization, factors which are designed to meet individual needs, are inherently supported within a UC environment. Individual recognition is supported through shared user profiles where users are uniquely identified by name, picture, and specific job function. Generally, users are able to choose specific UC features to implement that would most benefit different users, groups, or organizational units and customize as needed. Table 1 outlines the eight technology factors that impact relationship building as identified by Dillon and Montano (2005) inclusive of example features provided in UC platforms.

Table 1. Technology factors that impact relationships mapped to features of a UC platform

\begin{tabular}{|l|l|l|}
\hline \multicolumn{1}{|c|}{ Factors* } & \multicolumn{1}{|c|}{ Definition } & \multicolumn{1}{c|}{ Example UC Feature } \\
\hline Performance Factors & $\begin{array}{l}\text { The degree to which technol- } \\
\text { ogy makes communication } \\
\text { easier, requiring less effort. }\end{array}$ & $\begin{array}{l}\text { UC users can easily switch between } \\
\text { communications channels such as instant } \\
\text { messaging and voice by simply clicking } \\
\text { an option rather than dialing a number } \\
\text { and people can be easily added to a con- } \\
\text { versation by simply 'dragging' an image } \\
\text { across a computer screen. }\end{array}$ \\
\hline Informativeness & $\begin{array}{l}\text { The degree to which technol- } \\
\text { ogy is capable of providing } \\
\text { the desired information. }\end{array}$ & $\begin{array}{l}\text { Users have instant access to profile in- } \\
\text { formation and contextual presence track- } \\
\text { ing that provides user availability and } \\
\text { user status (such as in a meeting, on a } \\
\text { conference call, online, away from desk, } \\
\text { etc.). }\end{array}$ \\
\hline Relevancy & $\begin{array}{l}\text { The degree to which technol- } \\
\text { ogy is pertinent to the rela- } \\
\text { tionship. }\end{array}$ & $\begin{array}{l}\text { Users have the ability to choose an ap- } \\
\text { propriate communications medium from } \\
\text { a multitude of options. }\end{array}$ \\
\hline
\end{tabular}




\begin{tabular}{|c|c|c|}
\hline Factors* & Definition & Example UC Feature \\
\hline \multicolumn{3}{|l|}{$\begin{array}{l}\text { Human Factors: } \\
\text { Unifying }\end{array}$} \\
\hline Connection & $\begin{array}{l}\text { The degree to which a tech- } \\
\text { nology causes individuals to } \\
\text { feel linked to groups or the } \\
\text { organization. }\end{array}$ & $\begin{array}{l}\text { Organizational membership is main- } \\
\text { tained within sharable user profiles and } \\
\text { accessed by highlighting a person's name. } \\
\text { Organizations may also customize spe- } \\
\text { cific group settings or enable features } \\
\text { based on a group's role and responsibil- } \\
\text { ity. Further, individual users can create } \\
\text { teams or setup a 'hunt group' where } \\
\text { phones ring at the same time for all } \\
\text { members of a specified group. }\end{array}$ \\
\hline Membership & $\begin{array}{l}\text { The degree to which technol- } \\
\text { ogy prompts individuals to } \\
\text { feel part of a group or organ- } \\
\text { ization. }\end{array}$ & $\begin{array}{l}\text { UC allows for the setup of restrictive } \\
\text { group meetings, the ability to provide } \\
\text { team only access to calendar infor- } \\
\text { mation, and allows individuals to be in- } \\
\text { vited to private group discussions. }\end{array}$ \\
\hline Entitlement & $\begin{array}{l}\text { The degree to which technol- } \\
\text { ogy supports individuals feel- } \\
\text { ing they have a right to some- } \\
\text { thing because of their rela- } \\
\text { tionship to a group or organi- } \\
\text { zation. }\end{array}$ & $\begin{array}{l}\text { Certain features or aspects of UC may } \\
\text { be rolled out only to a specific group } \\
\text { based upon their role within the organi- } \\
\text { zation. }\end{array}$ \\
\hline \multicolumn{3}{|l|}{$\begin{array}{l}\text { Human Factors: } \\
\text { Distinguishing }\end{array}$} \\
\hline Differentiation & $\begin{array}{l}\text { The degree to which technol- } \\
\text { ogy enables individuals to be } \\
\text { recognized as important and } \\
\text { treated as unique. }\end{array}$ & $\begin{array}{l}\text { Through shared user profiles, individuals } \\
\text { are identified by name, by picture and by } \\
\text { specific job function. Many UC prod- } \\
\text { ucts also allow users to add other per- } \\
\text { sonalization identifiers such as emoti- } \\
\text { cons. }\end{array}$ \\
\hline Customization & $\begin{array}{l}\text { The degree to which technol- } \\
\text { ogy may be tailored to the } \\
\text { needs of the organization. }\end{array}$ & $\begin{array}{l}\text { Organizations may choose which fea- } \\
\text { tures of UC would benefit various users, } \\
\text { groups or organizational units and cus- } \\
\text { tomize as needed. }\end{array}$ \\
\hline
\end{tabular}

The literature provides insights into the potential of UC to impact productivity but research-based evidence on factors that contribute to productivity gains as a result of a UC implementation are scarce. In this study, we explore user perceptions of the impact of UC on productivity in three ways:

- assessment of user preference for UC features

- investigation of how users define productivity and associate UC with productivity gains

- examination of how UC impacts relationship building and if, this in turn, impacts user perceived productivity. 


\section{THE STUDY}

This study was conducted using a qualitative research approach through case study analysis. The need for case study research arises when there is a desire to understand and contribute to knowledge about a social phenomenon (Myers, 1997), in this case, intercommunication amongst employees within a large multi-national corporation facilitated through the implementation of a UC platform. The use of unified communications has become the communications standard for Hewlett Packard (HP), who has more than 300,000 employees located around the world. HP implements UC through the Microsoft's Skype for Business [formerly known as Lync] product (Microsoft, 2017).

Skype for Business incorporates many features. Companies are able to select and customize various options. HP chose to implement Chat, Click-to-Talk, Ad Hoc Conferencing, Video, PC Phone, and Scheduled Conferencing. These features are designed to enhance the communication experience. For example, chat or instant messaging is available even when users are engaged in other activities, such as participating in a conference call. Click-to-Talk instantly turns a chat conversation into a voice call with the simple click on a contact's name or image. Ad Hoc Conferencing, by a simple drag and drop action, allows real-time addition of new participants to a conference call. Scheduled Conferencing is easily synced to a Microsoft Outlook calendar. UC is a major advancement forward; previously various communications channels, such as voice, chat, and conference calls, were provided via separate and distinct products or services.

\section{PARTICIPANTS}

The study was conducted within the Global IT Infrastructure and Operations organization at the Hewlett Packard Company. Participants included members of the Global Telecom (GT) support team and the Global Real Estate IT organization, all of whom are tasked with supporting the HP worldwide telecomm infrastructure. Participants were chosen based on geographical location and work requirements that necessitated regular interaction with team members. It should be noted that, in many cases, team members had never met in-person. Details describing the work group and geographical location of the 30 study participants are outlined in Table 2.

Table 2. Participants by work group and geographical location

\begin{tabular}{|l|l|}
\hline Organization & Number of Participants \\
\hline GT Voice Engineering & 9 with 6 in the US and 3 in Asia Pacific \\
\hline GT Data Engineering & 3 , all in the US \\
\hline GT Voice and Data PMO & 3, all in the US \\
\hline GT Telecom Expense and Planning & 3 with 2 in the US and 1 in Europe \\
\hline GT Applications Engineering & 4 , all in the US \\
\hline GRE IT & 8 with 2 in the US, 3 in Europe, and 3 in Asia Pacific \\
\hline
\end{tabular}

\section{DATA COLLECTION AND ANALYSIS}

In-depth interviews with each participant were conducted via the UC tool used by HP. To ensure participant anonymity, each participant was assigned a pseudonym name. Participant ages ranged from 28 to 56 years of age. All participants had extensive experience in the field. Time of employment at HP ranged from two to 30 years. Those with five or less years at the company had worked at other corporations prior to joining HP. UC usage data was obtained by asking the participants to rank their preference and use of the various $\mathrm{UC}$ features. Interview narratives were examined using an open coding technique in order to capture individual perceptions of productivity. Using a matrix structure, specific respondent comments were organized by the three factors of human relationships [performance, unifying, and distinguishing] as described by Dillon and Montano (2005). 


\section{FINDINGS}

Participants were asked to rank their usage levels of the various features of UC implemented within HP. Usage levels, using a scale of 1-6, with 6 being least used, are depicted in Figure 2. The most used features of $\mathrm{UC}$ were email and chat. These findings are consistent with other research that examined technology use by global team members. Preference for email and chat has been attributed to visual anonymity, which reduces the importance of surface-level diversity (easily identifiable traits such as age and ethnicity) and overcomes cultural barriers (Carte \& Chidabaram, 2004). The use of these tools has also been found to increase self-disclosure behavior resulting in positive and beneficial interpersonal communication that ultimately supports relationship creation (Lowry et al., 2011). Video conferencing, as denoted by the tallest bar in the graph, was least utilized.

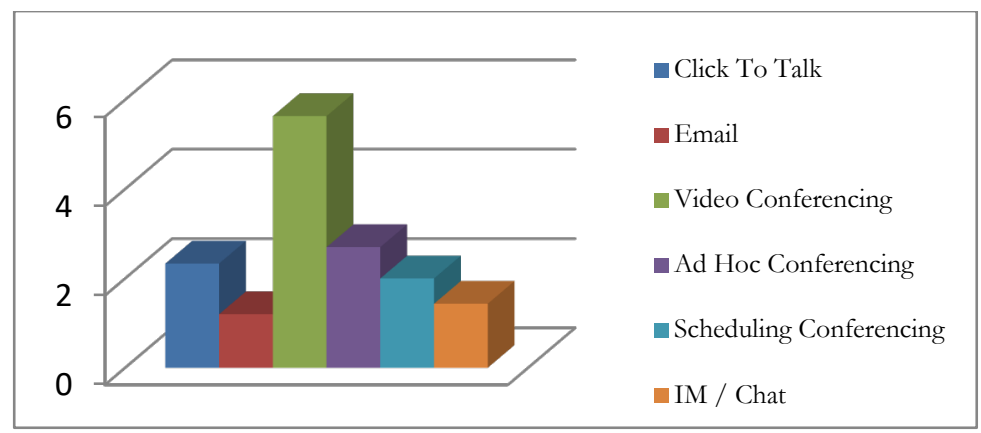

Figure 2. UC Feature Usage

To truly develop an understanding of how UC fosters productivity, it is important to investigate how users define productivity. Open coding techniques were used to discover common factors of productivity evidenced in study participant interviews. Four factors, including efficiency, speed, multi-tasking, and the development of interpersonal relationships, were revealed. In terms of efficiency, participants expressed that cost-saving was a primary benefit of UC. Specifically, users noted that UC supplants the high costs of cell phone usage, long distance calling, and external conferencing services, all without loss in communications quality. Speed or a decrease in the amount of time it takes to get work done was cited as a factor of productivity by $26(87 \%)$ participants. One respondent claimed that UC "accelerates the speed of business." UC was attributed to increasing employee availability, flexibility, and accessibility. UC removes the constraints of traditional communications protocols that often require prior scheduling, result in 'phone tag', or confine communication to a specific location. Participants providing feedback in regard to multi-tasking noted that UC enables employees to tend to other tasks while engaged in a communications activity such as a conference call or chat session. UC also supports participation in multiple communications channels at the same time. For example, users are able to conduct multiple chat sessions or initiate a chat session while participating in a conference call. This capability was cited to be extremely useful as it improves timely access to resources. One participant described the situation where a senior executive raised questions during a meeting and he was able to obtain answers from non-meeting participants before the meeting ended. Overall, participants in this study associated UC and its role in facilitating the development of interpersonal relationships with increased productivity. Many stated UC provides an improved communication flow fostering stronger relationships among team members contributing to enhanced collaboration, heightened creativity, and a better quality of work. Table 3 summaries participant perceptions of UC contributions to productivity gains. 
Table 3. Factors of Productivity Associated with Unified Communications

\begin{tabular}{|l|l|l|l|}
\hline $\begin{array}{l}\text { Factor of } \\
\text { Productivity }\end{array}$ & Definition & $\begin{array}{l}\text { Number of } \\
\text { Respondents }\end{array}$ & $\begin{array}{l}\text { Role of Unified Communi- } \\
\text { cations }\end{array}$ \\
\hline Efficiency & $\begin{array}{l}\text { The ability to save costs while } \\
\text { getting the job done. }\end{array}$ & 4 & $\begin{array}{l}\text { Supplants the high cost of } \\
\text { other communications chan- } \\
\text { nels such as cell phone usage, } \\
\text { long distance calling and con- } \\
\text { ferencing services without } \\
\text { reducing quality. }\end{array}$ \\
\hline Speed & $\begin{array}{l}\text { The ability to complete tasks } \\
\text { and resolve issues more quick- } \\
\text { ly. }\end{array}$ & 26 & $\begin{array}{l}\text { Accelerates the speed of } \\
\text { business by increasing em- } \\
\text { ployee availability, flexibility } \\
\text { and accessibility. }\end{array}$ \\
\hline Multi-tasking & $\begin{array}{l}\text { The ability to work on more } \\
\text { than one task at the same } \\
\text { time. }\end{array}$ & 12 & $\begin{array}{l}\text { Supports participation in } \\
\text { multiple and simultaneous } \\
\text { communication venues and } \\
\text { information sharing activities. }\end{array}$ \\
\hline $\begin{array}{l}\text { Development of } \\
\text { interpersonal } \\
\text { relationships }\end{array}$ & $\begin{array}{l}\text { The ability to build interper- } \\
\text { sonal relationships with } \\
\text { teammates enhancing collabo- } \\
\text { ration and creativity. }\end{array}$ & 23 & $\begin{array}{l}\text { Provides an improved com- } \\
\text { munication flow that fosters } \\
\text { stronger relationships among } \\
\text { team members leading to bet- } \\
\text { ter quality work products and } \\
\text { work life. }\end{array}$ \\
\hline
\end{tabular}

The role UC plays in facilitating relationship building and its connection to perceived productivity was further examined using the performance-based and human-based technology factors that impact relationships within an organization as identified by Dillon and Montano (2005). Participants provided strong evidence that performance factors were supported within an UC environment. In fact, all participants provided feedback demonstrating informativeness. Features most often cited were presence management that make it expedient to identify who is available to answer questions, persistent access to contact profiles through which a 'click and drag' dynamically adds a person to an-going conference, and desktop sharing that facilitates real-time exchange of information. Participants noted that having the right information at the right time is a contributing factor to improving productivity. Another major strength of UC is that it makes communication easier. Examples exemplifying convenience were provided by $28(93 \%)$ participants. The integration of multiple communications mediums and features, such as Click- to-Talk and the ability to auto join a conference call, reduce the steps and time it takes to open a communications channel. UC also supports relevancy, most notably by allowing users to select the communications medium most appropriate for the task at hand. Participants noted that they are now communicating with team members more frequently and often informally. Informal conversations promote self-expression and elicit personal interaction. UC was described as 'breaking down the walls of the cubicle' eliminating physical barriers that often impede effective communication. Table 4 summarizes participant responses providing evidence that UC embodies the performance factors that facilitate relationship building. 
Table 4: Evidence of Performance Factors of Technology

\begin{tabular}{|l|l|l|l|}
\hline $\begin{array}{l}\text { Performance } \\
\text { Factor }\end{array}$ & Definition & $\begin{array}{l}\text { Number of } \\
\text { Respondents }\end{array}$ & $\begin{array}{l}\text { Role of Unified Communi- } \\
\text { cations }\end{array}$ \\
\hline Informativeness & $\begin{array}{l}\text { The degree to which technol- } \\
\text { ogy makes communication } \\
\text { easier, requiring less effort. }\end{array}$ & 30 & $\begin{array}{l}\text { UC features including pres- } \\
\text { ence, persistent access to con- } \\
\text { tact profiles, and desktop shar- } \\
\text { ing facilitate real-time exchange } \\
\text { of information. }\end{array}$ \\
\hline Convenience & $\begin{array}{l}\text { The degree to which technol- } \\
\text { ogy is capable of providing } \\
\text { the desired information. }\end{array}$ & 28 & $\begin{array}{l}\text { Multiple communications op- } \\
\text { tions accessed via a consistent } \\
\text { user interface reduce the steps } \\
\text { and time it takes to open a } \\
\text { communications channel. }\end{array}$ \\
\hline Relevancy & $\begin{array}{l}\text { The degree to which technol- } \\
\text { ogy is pertinent to the rela- } \\
\text { tionship. }\end{array}$ & 27 & $\begin{array}{l}\text { The ability for users to dynam- } \\
\text { ically select the communica- } \\
\text { tions medium most appropri- } \\
\text { ate for the task at hand facili- } \\
\text { tates more frequent communi- } \\
\text { cation and the opportunity for } \\
\text { more personal interaction. }\end{array}$ \\
\hline
\end{tabular}

Participants were less definitive on whether human performance factors of technology that impact relationship building were supported by UC. Unifying human factors of connection and membership were evidenced by a majority of respondents with comments indicating UC makes connecting with teammates easier and promotes a sense of belonging. These are especially important to groups with members located throughout the globe. For example, one respondent stated that UC makes a global operation more intimate as all group members are working within the same virtual environment initiating communication with another team member becomes analogous to "feeling comfortable knocking on someone's door." UC also provides more opportunities to engage in informal modes of communication. One respondent noted that informality makes one feel a closer affinity to team members, especially team members located in different localities. Another participant noted that as communication among group members increases so does a sense of connection making the work environment feel "more personal." On the other hand, very few participants stated anything that related to entitlement, or a feeling of a right to something because of membership in a group or organization. Three participants did suggest an expectation of expeditious responses from fellow UC users with whom they had established a relationship. Another respondent noted once a relationship was established, it was more acceptable to respond with a simple 'yes' or 'no' without the perception of being rude.

Distinguishing factors of human performance include differentiation and customization. Comments related to differentiation, or the degree to which UC enables each participant to be recognized as important and treated as unique, were somewhat vague. Comments most closely related to differentiation were often associated with individual credibility and recognition for roles performed within the organization. For example, profiles including personalized user information, such as job titles, are made available to other users within the same UC environment. The general consensus appeared to be that UC promotes feelings of equality and accessibility. UC does not inhibit one's ability to approach another individual regardless of that person's role or status in the company. Customization of UC is possible at multiple levels. Features and functions of a UC implementation can be selected based on organizational need. For example, the call and conference recording feature was not im- 
plemented by HP as there were concerns it might violate the privacy policies of some countries. Participants appreciated the ability to customize at the user level. The feature most often customized was video; video was turned off when it did not add value. Overall, most acknowledged that customization allowed them to use the technology to fit their needs. Table 5 summarizes participant evidence for both unifying and distinguishing human factors of technology that have been found to facilitate relationship building within an organization.

Table 5: Evidence of Human Factors of Technology in UC

\begin{tabular}{|c|c|c|c|}
\hline Human Factor & Definition & $\begin{array}{l}\text { Number of } \\
\text { Respondents }\end{array}$ & $\begin{array}{l}\text { Role of Unified Communi- } \\
\text { cations }\end{array}$ \\
\hline $\begin{array}{l}\text { Unifying Factor: } \\
\text { Connection }\end{array}$ & $\begin{array}{l}\text { The degree to which a tech- } \\
\text { nology causes individuals to } \\
\text { feel linked to groups or the } \\
\text { organization. }\end{array}$ & 25 & $\begin{array}{l}\text { UC makes connecting with } \\
\text { teammates easier thereby } \\
\text { promoting a sense of belong- } \\
\text { ing. }\end{array}$ \\
\hline $\begin{array}{l}\text { Unifying Factor: } \\
\text { Membership }\end{array}$ & $\begin{array}{l}\text { The degree to which tech- } \\
\text { nology prompts individuals } \\
\text { to feel part of a group or } \\
\text { organization. }\end{array}$ & 16 & $\begin{array}{l}\text { UC provides more opportu- } \\
\text { nities to engage in informal } \\
\text { modes of communication } \\
\text { creating closer connections } \\
\text { between team members. }\end{array}$ \\
\hline $\begin{array}{l}\text { Unifying Factor: } \\
\text { Entitlement }\end{array}$ & $\begin{array}{l}\text { The degree to which tech- } \\
\text { nology supports individuals } \\
\text { feeling they have a right to } \\
\text { something because of their } \\
\text { relationship to a group or } \\
\text { organization. }\end{array}$ & 3 & $\begin{array}{l}\text { UC increases the expectation } \\
\text { of expeditious responses } \\
\text { from fellow UC users. }\end{array}$ \\
\hline $\begin{array}{l}\text { Distinguishing Fac- } \\
\text { tor: Differentiation }\end{array}$ & $\begin{array}{l}\text { The degree to which tech- } \\
\text { nology enables individuals } \\
\text { to be recognized as im- } \\
\text { portant and treated as } \\
\text { unique. }\end{array}$ & 4 & $\begin{array}{l}\text { Through shared user profiles, } \\
\text { individual contributions to } \\
\text { the organization can be noted } \\
\text { and recognized. }\end{array}$ \\
\hline $\begin{array}{l}\text { Distinguishing Fac- } \\
\text { tor: Customization }\end{array}$ & $\begin{array}{l}\text { The degree to which tech- } \\
\text { nology may be tailored to } \\
\text { the needs of the organiza- } \\
\text { tion. }\end{array}$ & 24 & $\begin{array}{l}\text { Customization is possible at } \\
\text { multiple levels, much of it } \\
\text { under the control of the indi- } \\
\text { vidual user. }\end{array}$ \\
\hline
\end{tabular}

\section{SUMMARY OF THE FINDINGS}

Overall, the findings suggest that features of $\mathrm{UC}$ facilitate better and easier communication in the workplace. UC provides support for efficiency, speed, multi-tasking, and developing interpersonal relationships. These functions increase perceptions of productivity as users feel more efficient in doing their jobs because UC reduces costs, decreases the time it takes to get work done, and affords the ability to work on multiple tasks at the same time. These productivity gains stem from the fact that UC increases employee flexibility, accessibility, and availability resulting in an increased communication flow. Features most often cited as beneficial were the ability to dynamically choose the communications medium most appropriate for the task at hand, the ability to simultaneously use multiple communications channels, the ease of being able to instigate multi-party ad-hoc conversations, and presence management. 
Aside from email, chat was cited as the most used feature of UC. The use of this tool aligns with users' perceptions of the impact of UC on productivity. Chat allows for multiple windows to be opened at the same time, allows for concurrent chat sessions to be maintained, and, if a voice call is warranted, only requires 'the click of a mouse' to turn a chat into a voice call. Further, the ease of use of chat lends itself well to informal conversations and self-disclosure (Lowry et al., 2011). Selfdisclosure, which is noted as an action with the purpose of expressing feelings, establishing credibility, or interacting socially, is associated with relationship building. Interestingly, the least used feature of UC is video conferencing as most respondents did not see an added value to using this technology to successfully complete their work.

The findings show that the features of UC support relationship building and that a connection exists between perceptions of productivity and good working relationships. Dillon and Montano (2005) identified a set of factors that when inherent in a technology impact organizational relationships. Study respondents overwhelmingly indicated that UC met the performance factors that enhance the usability of a technology to facilitate relationship building. They also felt that UC promoted more interchange between group members. The use of UC made them feel more approachable and on a level playing field with all members within the organization regardless of title or role in the company. They also felt that UC made communication more successful between group members regardless of geographical location. UC helps to remove cultural barriers generating higher levels of respect for those with diverse backgrounds. UC also made communication less formal and therefore gave users the freedom to express themselves in ways not acceptable in formal modes of communication. Consequently, the tools within UC create a means to form relationships more naturally. The resultant increase in communication frequency fosters a stronger sense of connectedness between members as well as a stronger sense of belonging. Ultimately, the use of UC leads to an increased perception of productivity as both technical and social barriers to communication are reduced.

\section{CONCLUSION}

Unified Communications transforms business communication. Through integration of disparate communications technologies and information sharing applications, UC changes the way communication occurs within the work environment. The features of UC -- convenience, ease-of-use, and $24 \times 7$ availability -- enhance employee performance and increase workplace productivity. We postulate that these enhancements are predicated on a strengthening of relationships that occurs as a result of improved communication. The key here is communication and in order to have a good communication flow, some form of relationship must exist. As employees become more familiar with those to whom they communicate, accessibility and approachability is enhanced and conversations become more efficient and effective. The ease of communication afforded by UC supports improved relationship building as users are able to establish more personal interactions with each other. Relationships among team members contributes to a willingness to be more responsive, provide more assistance, and do more favors that, in turn, increases perceptions of productivity. Further, this new communications landscape leads to knowledge sharing and idea generation - traits associated with highly productive and successful organizations. The results of this study support the model that improved channels of communications, as provided by UC, lead to better communication between coworkers facilitating relationship building, and, stronger relationships have a positive impact on productivity in the workplace.

It is hard to measure the return of investment realized through unified communications (Arnold, 2015). It is also hard to measure its impact on productivity. However, the findings of this study demonstrate ways in which UC increases perceptions of productivity and, as such, can be used to assess how UC might generate the greatest benefit for an organization. From a functional perspective, UC improves workflow, reduces costs, and facilitates multi-tasking; in other words, work is getting done faster and issues are being resolved more quickly. $\mathrm{UC}$ is location neutral - employees can work from any location with broadband access. UC also fosters stronger working relationships that 
help to create positive work environments. UC does this, not by replacing commonly used communications options, but by providing a new and innovative way of using those communications channels in a more effective and efficient manner (Arnold, 2015).

Unified communications will play an increasingly important role as people adapt to the evolving digital world through which they communicate and collaborate. The necessity of UC in the workplace has been widely acclaimed by industry research groups such as Gartner and by anecdotal case studies by vendors. According to Greengard of CIO Insight (2013), UC has moved from a cost-savings venture into a mission critical strategy as it is touted to increase employee productivity via streamlined business workflows, improved collaboration between employees, business partners, and customers, and increased innovation fostered through knowledge sharing and knowledge transfer (Riemer \& Taing, 2009). This research contributes to studies on the impact of UC in the workplace by examining employee perceptions of how UC improves productivity. It also provides an understanding of the role UC plays in relationship building in environments where collaboration is required to complete tasks. The findings of this study will aid organizations in making investment decisions for more progressive and effective business communications strategies.

\section{REFERENCES}

Arnold, J. (2015). Four ways unified communications benefits productivity. TechTarget. Retrieved from http://searchunifiedcommunications.techtarget.com/feature/Four-ways-unified-communications-benefitsproductivity\#.WGkYfF6ZFbY.email

Bolton, A, Murray, M., \& Fluker, J. (2017). Transforming the workplace: Unified communications \& collaboration usage patterns in a large automotive manufacturer. Proceedings of the 50th Hawaii International Conference on System Sciences, Waikoloa Village, HI. Retrieved from http://hdl.handle.net/10125/41823

Carte, T. A., \& Chidambaram, L. (2004). A capabilities-based theory of technology deployment in diverse teams: Leapfrogging the pitfalls of diversity and leveraging its potential with collaborative technology. Journal of the Association for Information Systems, 5(11-12), 448-471.

Cross, N. (2013). Taking a collaborative approach to business with unified communications. Credit Control, $34(2), 45-49$.

Dillon, R., \& Montano, B. R. (2005). The impact of technology on relationships within organizations. Information Technology and Management, 6(2-3), 227-251.

Elliot, B., Blood, S., \& Fernandez, M. M. (2016). Magic quadrant for unified communications. Gartner Research. Retrieved from https://www.gartner.com/doc/reprints?id=1-3BON1KW\&ct=160714\&st=sb

Ferris, G. R., Linden, R. C., Munyon, T. P., Summers, J. K., Basik, K. J., \& Buckley, M. R. (2009). Relationships at work: Toward a multidimensional conceptualization of dyadic work relationships. Journal of Management, 35(6), 1379.

Gartner, Inc. (2013). Unified communications. Gartner IT Glossary. Retrieved from http://www.gartner.com/itglossary/unified-communications-uc

Grand Review Research. (2015). Unified communications market analysis by product (on premise, cloud-based/hosted), by application (education, enterprise, government, bealthcare) and segment forecasts to 2020. Retrieved from http://www.grandviewresearch.com/industry-analysis/unified-communication-market

Greengard, S. (2013). Reaping the benefits of unified communications. CIO Insight, Online. Retrieved from http://www.cioinsight.com/it-strategy/messaging-collaboration/reaping-the-benefits-of-unifiedcommunications

Inman, R. A. (2015). Productivity concepts and measures. Reference for Business. Advameg, Inc. Retrieved from http://www.referenceforbusiness.com/management/Pr-Sa/Productivity-Concepts-and-Measures.html

Jääskeläinen, A., \& Uusi-Rauva, E. (2011). Bottom-up approach for productivity measurement in large public organizations. International Journal of Productivity and Performance Management, 60(3), 252-267.

Jamison, N., \& Pleasant, B. (2008). UC end user productivity study. Unified Communications Strategies, 1-25. 
Kongkiti P., Anussornnitisarn, P., Sujitwanit, S., \& Kess, P. (2009).Profile-based circumstances for productivity measurement. Industrial Management + Data Systems, 109(6), 825-839.

Kristensen, K., \& Kinjal, B. (2010). Collaborative performance: Addressing the ROI of collaboration. International Journal of E-Collaboration, 6(1), 53.

Kunsoo, H., Young, B. C., \& Jungpil, H. (2010). Information technology spillover and productivity: The role of information technology intensity and competition. Journal of Management Information Systems, 28(1), 115-145.

Lowry, P. B., Cao, J., \& Everard, A. (2011). Privacy concerns versus desire for interpersonal awareness in driving the use of self-disclosure technologies: The case of instant messaging in two cultures. Journal of Management Information Systems, 27(4), 163-200.

Microsoft. (2017). Skype for Business. Retrieved from https://products.office.com/en-us/skype-forbusiness/compare-plans?wt.srch=1\&wt.mc id=AID522514 SEM hI9oduCW

Myers, M. D. (1997). Qualitative research in information systems. MIS Quarterly, 21(2), 241-242.

Pleasant, B. \& Jamison, N. (2008). UC end user productivity: How end users are finding value from unified communications. Unified Communications Strategies, 1-10.

Riemer, K. \& Taing, S. (2009). Unified communications, Business \& Information Systems Engineering, 1(4) 326-330.

Weihua, Z. (2011, October). Research on E-government information service mechanism based on unified communication technology. Proceedings of the 2011 International Conference on Image Analysis and Signal Processing, Wuhan, Hubei, China, 56-61. Doi: 10.1109/IASP.2011.6108997

\section{BIOGRAPHIES}

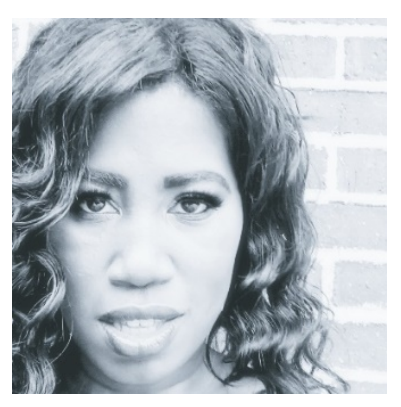

Joy Fluker is an IT professional with more than 14 years of experience in industry serving in roles including program management, portfolio management, and business relationship management, at Hewlett Packard Company, and most recently at General Motors Corporation. She holds a Doctorate of Science in Information Systems and her current research focuses on unified communications in the workplace, specifically assessing its impact on perceived productivity and relationship building. Dr. Fluker also teaches in higher education in the areas of information systems and computer science.

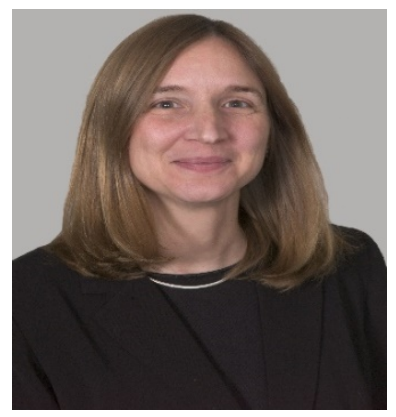

Meg Murray is a professor of information systems who holds a joint appointment in the Coles College of Business and the University College at Kennesaw State University. She holds a Ph.D. in information systems and has over thirty years of experience in both academe and industry. Dr. Murray specializes in the development and implementation of emerging technologies to meet educational, business and societal needs. Her current work devises strategies to assess, remediate and amplify skills students need to leverage IT in innovation, a primary driver of economic growth 